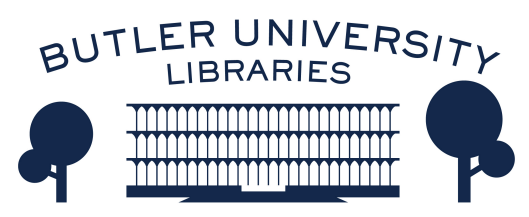

Journal of Hindu-Christian Studies

Volume 8

Article 3

January 1995

\title{
Four Responses to Prof. Dharampal's "Bharatiya Chitta Manas and Kala"
}

Francis X. Clooney

Follow this and additional works at: https://digitalcommons.butler.edu/jhcs

Part of the Religion Commons

\section{Recommended Citation}

Clooney, Francis X. (1995) "Four Responses to Prof. Dharampal's "Bharatiya Chitta Manas and Kala"," Journal of Hindu-Christian Studies: Vol. 8, Article 3.

Available at: https://doi.org/10.7825/2164-6279.1108

The Journal of Hindu-Christian Studies is a publication of the Society for Hindu-Christian Studies. The digital version is made available by Digital Commons @ Butler University. For questions about the Journal or the Society, please contact cbauman@butler.edu. For more information about Digital Commons @ Butler University, please contact digitalscholarship@butler.edu. 


\title{
Four Responses to Prof. Dharampal's Bhāratīya Chitta Manas and Käla
}

\author{
Francis Clooney, S.J. \\ Boston College
}

\section{Introduction}

FOR DECADES PROF. Dharampal has been well-known and respected for his research on eighteenth-century India; his analyses of a wide range of social, cultural, political, economic and technological issues have been respected and valued during this time. Bhāratĩya Chitta Manas and Käla perhaps, "The Indian Sense of Consciousness, Mind and Time" - is both a continuation of his earlier work and a new venture in reflection on larger and more elusive religious and cultural issues. In introducing the book, Jitendra Bajaj, Director of the Centre for Policy Studies in Madras (with which Prof. Dharampal has been associated in recent years), tells us that Prof. Dharampal wrote the essay (in Hindi) because he has begun to feel

\begin{abstract}
that though his historical studies have to some extent helped him understand the ways in which the Indians prefer to organize the physical world around them, yet he has failed to comprehend the Mind that provides the anchorage for these typically Indian ways, preferences and seekings. And, to learn about this anchorage, to understand the Indian Chitta and Kāla, as he puts it, he began a study of the Indian classical literature (9). ${ }^{1}$
\end{abstract}

In this new reflective venture Prof. Dharampal remains an attentive observer of Indian history, its habits and symbols, of what makes sense to Indians and motivates them, and what remains foreign and unpersuasive; he has a good eye too for the styles, strengths and weaknesses of modern scholarship, Indian and western; he cares deeply about his theme and his research is imbued with his personal convictions and questions. His key point is perhaps the one expressed at the end of chapter 4 and beginning of 5 (47-8): Indians do have a unique sense of the world order and of time, of the human place in relation to all of reality - and therefore they $d o$ have a different attitude toward technology and progress, learning, universities, etc. India must recover its sense of itself and stop imitating the West, if it is to flourish as a coherent culture - it can and must do this.

Bhāratīya Chitta Manas and Kāla was released with great fanfare during a Srīvaisnava conference in Madras in March 1993; the chief guest at the event was the revered Tridandi Chinna Srimannarayana Ramanuja Jeear Swami, founder of the Jeear Educational Trust and Veda Viswavidyalayam at Vijayawada, Andhra Pradesh; if the conference was a celebration of tradition and heritage at the end of the twentieth century, this book is perhaps the clearest enduring mark of the conference. Even at that time it was clear to me that great hopes were invested in the book, as a real contribution to a new intellectual atmosphere in contemporary India, and rightly so. It is thoughtful, bold and provocative, it invites and deserves responses in kind - hence this issue of the Hindu-Christian Studies Bulletin. Before turning to four invited responses, however, I offer an outline of the book's six chapters along with some key passages from the book. 


\section{Outline and excerpts}

Key Points in Chapter I: the power and limits of Gandhi's influence on Indian culture; India as confined to the West's twentieth century; India's need to rediscover its own identity, ways of thinking and living.

Excerpts from Chapter I: We the educated elite of India are wary of any attempt to understand the Indian mind. Many of us had felt uneasy even about Gandhiji's efforts to delve into the Chitta and Kāla of the people of India and voice what he perceived to be their innermost thoughts and feelings. We are somehow afraid of those inner thoughts of the people of India. We want to proceed with the myth that there is nothing at all in the Indian mind, that it is a clean slate on which we have to write a new story that we ourselves have painstakingly learnt from the West. But we are also probably aware that the Indian mind is not such a clean slate. In reality it is imbued with ideas on practically all subjects. Those ideas are not new... From whatever source and at whatever epoch the various ideas that dominate the minds of the Indian people have arisen, those ideas are indeed etched very deep. Deep within, we, the elite of India, are also acutely conscious of this highly elaborate structure of the Indian mind. We, however, want to deny this history of Indian consciousness, close our eyes to the long acquired attributes of the Indian mind, and wish to reconstruct a new world for ourselves in accordance with what we perceive to be the modern consciousness (17).

...Whose twentieth and twenty-first centuries are we so anxious about? The epoch represented by these terms has little to do with our Chitta and Kāla. The people of India, in any case, have little connection with the twentieth or the twenty-first century... The people of India, in fact, may not be living even in the eighteenth century of the West. They may still be reckoning time in terms of their Purānic conceptions... In any case the twentieth century is not the century of India (19).

Key Points in Chapter II: The limits of western Indology, which is the quintessential study of the conquered by the conquerors; the tendency of much research by Indians themselves to be industrious, yet quantitative rather than qualitative, eager but alienated; how can Indians recover the Indian past in a productive and properly Indian way?

Excerpts from Chapter II: There are probably many paths to an understanding of the Chitta and Kāla of a civilization. In studying the eighteenth-century Indian society and polity I traversed one such path. But that path led only to a sketchy comprehension of merely the physical manifestation of the Indian mind. It gave some understanding of the way Indians preferred to organize their social, political and economic life, when they were free to do so according to their own genius and priorities... To learn about the people of India, to try to understand the way they live, the way they think, the way they talk, the way they cope with the varied problems of day-to-day living, the way they behave in various situations - and thus to know in detail about the ways of the Indians - is perhaps another path to a comprehension of the Indian Chitta and Kāla. We are probably too far removed from the reality of Indian life to be able to perceive intelligently the ways in which the people of India live within this reality. It may be relatively easier to comprehend the Indian mind through the ancient literature of Indian civilization. In fact, the process of understanding the Indian Chitta and Kāla cannot possibly begin without some understanding of the vast corpus of literature that has formed the basis of Indian civilization and regulated the actions and thoughts of the people of India for millennia (22). 
Indology, by its very definition, is the science of comprehending India from a nonIndian perspective, and practically all Indian scholars and Indian institutions engaged in the study of Indian literature fall within the discipline of Indology. They have thus been trying to make India comprehensible to the world. But what we need to learn from Indian literature is how to make modernity comprehensible to us, in terms of our Chitta and Kāla, and to place the modern consciousness and modern times within that picture. Instead, our scholars have so far only been trying to place India, the Indian mind and Indian consciousness, within the world-picture of modernity (23).

Key Points in Chapter III: The divide between the theory and practice of Indian life; true Indian education as comprehensive of right intellect, right conduct, right meditation; the need for a holistic approach to Indian culture, neither Indological nor merely piecemeal.

Excerpt from Chapter III: If knowledge of Prajñ $\bar{a}$ [right intellect], Síla [right conduct] and Samädhi [right meditation] is what is called education in our tradition, then we have to understand this form of education. We also need to find out how many amongst us are educated in this sense of education. Perhaps there are not many Indians who may be called educated on this criterion. There many be only half a per cent of Indians who are educated in the practice of Prajñā, Síla and Samãdhi. Or, there may even be five per cent, for all we know. But supposing there are only half a per cent Indians who turn out to be educated in this sense of educated, even that number may be five or to ten times the number of people adept at Prajñā, Síla and Samädhi throughout the world. According to our own definition of education, therefore, we may be the most educated people in the world (36).

Key Points in Chapter IV: Indian notions of time and creation; the need for a retrieval of the four ages (yuga) of the world; the "smallness" of the human in the broader context of the universe.

Excerpt from Chapter IV: The major lesson of this Indian story of creation is of the smallness of man and his efforts in the vast drama of the Universe that has no beginning and no end. The cosmic play of creation unfolds on a very large scale, in time cycles of huge dimensions. In that large expanse of time and Universe, neither the man living in the simple bliss of Krta, nor the man caught in the complexity of Kali, has much significance. Simplicity and complexity, bliss and anxiety keep following each other. But the play goes on (47).

Key Points in Chapter V: The distinction of parā vidyä ("knowledge of the sacred") and aparā vidyã ("mundane knowledge"), and the way in which this distinction became reduced to a hierarchicai order, the "higher" and the "lower", with the former overvalued, the latter neglected; the negative influence of this attitude on social classification; how the theory of karma with its appreciation of intention is actually a corrective to caste thinking.

Excerpts from Chapter $V$ : The peculiarly Indian awareness of the insignificance of man and his efforts in the unending flow of Kāla is however not in consonance with modernity. The belief that in every new cycle the Universe, from the moment of its creation, starts declining towards a lower and lower state is also incompatible with modern consciousness... If the Indian understanding of the unfolding of the Universe, and the place of man and his efforts in it, is so contrary to the concepts of modernity, then this contrariness has to be seriously pondered over. The structures that we wish to implant in India and the processes of development that we want to initiate can take root here, only if they seem compatible with the Indian view of the Universe, with the Indian Chitta and Kāla. Structures and processes that are contrary to 
the picture of the Universe and its unfolding etched on the Indian mind are unlikely to find much response in India. At least the people of India, those who are still basically anchored in their own Chitta and Kāla, are unlikely to participate in any efforts that seem essentially alien to the Indian comprehension of the Universe (48).

Thus the Brāhmanas associated with the recitation and study of the Vedas become the highest, and the Sūdras engaged in the practice of the arts and crafts of ordinary living become the lowest. This hierarchy may not in reality be a fundamental aspect of classical Indian thought... the issue of the hierarchy of the Varnas is not a closed question in the Indian tradition. During the last two thousand years, there have occurred numerous debates on this question within the Indian tradition. And, in practical social life such a formulation of high and low could not have survived anyway. The concepts of the irreconcilability of the Parā Vidya and Aparā Vidy $\bar{a}$, and the corresponding asymmetry between the Brāhmana and the Súdra, could never have meant much in actual practice in any healthily functioning social organization... The imbalance seems to have arisen mainly through the interpretations of the canonical texts that have been made from time to time (52).

Comprehending and appreciating these various interpretations, and working out a new interpretation that falls within the ancient tradition and is yet capable of being related to the modern contexts, is perhaps the paramount task of Indian scholarship. This continuous reinterpretation and renewal of the tradition, continuous meditation on the ways of manifesting the Indian Chitta and Kāla in practical day-to-day life, and the continuous exploration of the Indian way of life in different times and different contexts, is what the Rsis, Munis and other great scholars of India have been concerned with through the ages (56).
Key Points in Chapter VI: Toward a positive appreciation of the Kali Yuga, the need for a heightened sense of compassion, and for deeper faith in the value of the Indian tradition as preferable to foreign cultural and religious values; the need for a new vision of the whole - like Arjuna's Viśvarüpadarśana in Bhagavad Gìtā 11)

Excerpts from Chapter VI: What matters, perhaps, is not the accuracy of an interpretation, but the sense of compassion that the interpreter feels for his fellow beings. It is this compassion, the concern for the state of all beings and respect for their efforts, even if these seem insignificant on the cosmic canvas, which makes a particular interpretation valuable. Only in light of such compassion and concern can we hope to make any meaningful new interpretations of the Indian Chitta and Kāla. Contemporary interpretation flowing from such transparent compassion and concern alone can have any chance of forming a secure basis for the reestablishment of the Indian way of life today. Interpretations that lack compassion, like the one about poverty and destitution being the result of one's own earlier Karmas, are not going to be of much help in such an effort (58-9).

What is of significance is always the present. If we wish to affirm the validity of Indian consciousness, of Indian Chitta and Kāla, we can do so only by establishing the Indian way of life in the present-day world. And, this reassertion of India in the present context is the major task today which Indian scholarship, Indian politics, Indian sciences and technologies, Indian arts, drafts and other diverse skills must accomplish (59).

This at least can be said about all Indians, even about the ordinary Christians of India, that their Chitta and Kāla have little in common with modern European civilization. They are all equally alien in the world of European modernity. In fact, except for at most half a per cent of Indians, the rest of India has precious little to do with European modernity. Whatever else may be etched on 
the minds of these 99.5 per cent of Indians, there is nothing there that even remotely resembles the consciousness of the modern West or even that of ancient Greece or Rome. But in the unbounded flow of modernity almost every Indian seems to have lost the ability to express his innate consciousness even in small ways. Even his festivals, that in a way reminded him of his Kāla, and gave him, until recently, some little pleasure in his otherwise impoverished drab life, and even the most vital of his rituals, those of birth, marriage and death, that gave him a sense of belonging to the universe of his Chitta and Kāla, have fallen by the wayside... We have to find some way out of such a state of rootlessness. We have to somehow find an anchor again in our civilization's consciousness, in our innate Chitta and Kāla (60).

If all these efforts [at Christianization] had led to a thorough-going westernization of the Indian mind so that the people of India on their own could start associating themselves with the late twentieth and the twenty-first centuries of the West, then that perhaps would have been some sort of a solution to India's problems. If that change of Indian civilizational consciousness had taken place, then the ordinary Indian today would think and behave more or less like the ordinary man of Europe and America, and his priorities and seekings would have become similar. Indians would then have also lost the peculiarly Indian belief, which even the most ordinary of the ordinary Indians harbours in his heart, that he is a part of the ultimate Brahman, and by virtue of this relationship with Brahman, he too is completely free and sovereign in himself. In place of this feeling of freedom and sovereignty, that so exasperates those who seek to administer or reform India, the Indian too would have both acquired the western man's innate sense of total subordination to the prevailing system, a subordination of the mind that man in the West has always displayed irrespective of whatever the system was in any particular western phase... The consciousness of the Indian people would have also been modeled into the same state of subordination as that of the western man, if the attempts of the last two hundred years to westernize or Christianize India had reached anywhere (61-2).

If the westernization of India is not possible, then we shall have to revert to our own civilizational moorings. We shall have to come back into our own Chitta and Kāla. Ridding ourselves of the western ways of thought and action we shall have to start understanding ourselves and the world from our own civilizational perspective. This effort to understand ourselves and our Kāla will probably be similar to the way Vyāsa, in his Mahäbhārata, surveys the complete story of Indian civilization, explores its diverse seekings, its ways of thought and action, and then, shows a path that is appropriate to the Kali Yuga. Or, perhaps it will be like the way Srikrishna offers Arjuna a glimpse of the Universe and on the basis of that view of the world, the Viśvarüpa Darśana, shows him the way out of his dilemma. In any case, we shall have to form a view of the world and other present time, from our own perspective, before we can find a path of our own. This task of having a new Viśvarūpa Darśana for ourselves, and searching a path of action in the light of that Darśana, has to be performed by all those who are closely connected with the Indian tradition and have a deep sense of respect for it. It is, however, important that those involved in this exercise are motivated by compassion for fellow beings. And, for that to happen, the beliefs of the people of India and their ways of thought and action will have to be given priority over anything that is written in the texts (62).

Once we seriously get down to the task, it may not turn out to be too difficult to find a new direction for the Indian civilization. To redefine our seekings and aspirations, our ways of thought and action, in a form that is appropriate and effective in today's world 
may not be too hard a task after all. Such reassertions and redefinitions of civilizational thrust are not uncommon in world history. For every civilization there comes a time when the people of that civilization have to remind themselves of their fundamental civilizational consciousness and their understanding of the Universe and the Time. From the basis of that recollection of the past, they then define the path for their future. Many civilizations of the world have undergone such selfappraisal and self-renewal at different times. We ourselves, in our long history, must have many times engaged in this recollection and reassertion of the Chitta and Kāla of India. We need to undertake such an exploration into ourselves once again (64).

\section{Four responses to Bhāratīya Chitta Manas and Kāla}

What follows now is a small symposium in response to Prof. Dharampal's work; it is our hope that in this way the HinduChristian Studies Bulletin will contribute to this new, important and interesting conversation about Hinduism, its cultural and cross-cultural possibilities today: Is there an Indian mind? Is it to be discovered in the rich traditions of ancient India? What should Indians think of the West today, what should Hindus think of Christianity? How do religions modernize - when they do it well? Responses are offered here by four scholars who are themselves very much concerned with the issues Prof. Dharampal raises: in the United States, Anantanand Rambachan, Professor of Religious Studies at St. Olaf's College, and Lance Nelson, Professor of Religious Studies at University of San Diego; in India, Nilima Chitgopekar, Prof. of History at Jesus and Mary College, New Delhi, and Anand Amaladass, S.J., Direcior of the Institute for Philosophy and Culture, Madras. Professors Rambachan and Chitgopekar are Hindu, Professors Nelson and Amaladass Christian. As the reader will note, their responses are engaged, vigorous, critical, taking quite seriously the points raised by Prof. Dharampal; their comments are direct, frank and critical; they thus do honour to Prof. Dharampal's reflections, even when in disagreement with him.

We hope that the issues raised will become topics for lively discussion among readers of the Bulletin and members of the Society for Hindu Christian Studies; and we look forward to a response from Prof. Dharampal in the next issue of the Hindu Christian Studies Bulletin.

\section{Lance Nelson University of San Diego}

Prof. Dharampal evokes a sense of urgency as he calls India's westernized intelligentsia to a rediscovery of India's ethos and destiny. This task is essential, he feels, if India is to regain its bearings and revitalize its civilization. While he recognizes that the twentieth century is "the century of the West", he envisions a possible future century of India. Prof. Dharampal's essay and the project it describes reflects, of course, a global movement. Those who were colonized are seeking decolonization, as ethnic groups everywhere attempt to rediscover their cultural and religious identities in face of the homogenizing assault of modernity. 


\section{Prof. Dharampal's Bhäratīya Chitta Manas and Käla}

Speaking of the Indian psyche, Prof. Dharampal uses the Sanskrit word citta, emphasizing that citta contains subliminal impressions that condition all experience. This means that cultural values are "etched very deep" in the Indian mind, which has a "highly elaborate structure" that resists westernizing overlays (17). India's "innate consciousness" is something that India's elite cannot disconnect themselves from, Prof. Dharampal argues (60). They must make a conscious effort to recover it.

The primary method that Prof. Dharampal offers is a thoughtful reading of India's ancient Sanskrit literature. Unlike Roy and Dayananda, he favours the epics and Purānas over the Vedic-Upanishadic corpus. In particular, he seizes on purānic conceptions of the flow of time $(k \bar{a} l a)$ as the key to authentic Indian consciousness. India's masses, he suggests provocatively, "may not be living even in the eighteenth century of the West" (19). Rather, they are probably living in the Dark Age, the Kali Yuga. Prof. Dharampal challenges his readers to think what it means to relate to modernity from within such a horizon.

Certainly the sense of universe as play proceeding in cycles without beginning or end is deeply rooted in the Indian psyche. Surely this image provides the context for much that is distinctive about India. While the West sees human beings and their technology in an evolutionary perspective, Prof. Dharampal notes, the traditional Indian view rules out progress. Starting with an initial perfection, the cycles display an inexorable decline, over which human beings have little, if any, control. Traditional India looks on science and technology as symptoms of this descent. Its tools and devices are seen as "temporary human artifacts required to sustain life in a constantly decaying state of the Universe". Prof. Dharampal's conclusion: "If the Indian understanding $\ldots$ is so contrary to the concepts of modernity, then this contrariness has to be seriously pondered over" (48).
This is a promising start. Readers hoping for a courageous probing of this contrariness, however, will soon be disappointed. Having underscored how India is momentously different, Prof. Dharampal proceeds to minimize important aspects of that difference. His argument in this respect is unconvincing.

The traditional Hindu distinction between parā and aparā vidyās, sacred and mundane forms of knowledge, Prof. Dharampal believes, is not hierarchical, despite having become deeply ingrained in the Indian psyche as such. For centuries India's elites have esteemed "spiritual" knowledge over practical disciplines, for which they have had contempt. But this long-standing habit must be corrected. Prof. Dharampal argues that this false hierarchical conception of knowledge has vitiated India's understanding of both caste and karma. The idea that certain knowledge is higher led to the belief that certain actions were superior. This, in turn, led to a distorted hierarchical reading of caste. Gandhi's non-hierarchical view of caste, Prof. Dharampal claims, is more authentic. The ancient and well-known Purusa Sūkta, which shows Brāhmins originating from the mouth of the cosmic man and Südras from his feet, intends no hierarchy by this arrangement. The much revered Śankarācārya of Jyotir Math, the late Swami Brahmananda Sarasvati, is misreading the doctrine of karma when he states that poverty is a karmically determined state.

Perhaps. But when a scholar seeking the authentic spirit of traditional India implies that Hindus regard the head as ritually equal to the feet, one wonders. When he casually dismisses the teachings of a highly regarded spokesperson for traditional Hinduism with no supporting arguments, one must confess perplexity. Still, Prof. Dharampal's tactic here will be familiar to students of nineteenth-century reform Hinduism. What is disagreeable by the standards of modern western liberalism is not essential to the Hindu view, but a later accretion. Prof. 
Dharampal admits the need for a "new interpretation" of the Indian mind and sense of time. The standard he proposes is compassion, but the reader - confronted with his forced reading of the tradition begins to wonder whether "compassion" in this case is a back door for western egalitarian values. Prof. Dharampal himself asks Indian Indologists: "Why demean this ancient literature by imputing it with modernistic presentiments?" (27). Why indeed? Why not instead courageously continue the promised investigation into India's "contrariness"? Such an inquiry, pursued knowledgeably and resolutely, would be tremendously fruitful.

Prof. Dharampal avoids carefully

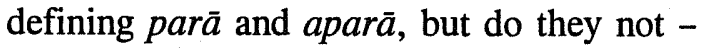
in this context - mean precisely "higher" and "lower", "superior" and "inferior"? Has Prof. Dharampal read Sankara? Caste may not have been a factor in the paradisal Krta Yuga, and Gandhi may have denied the hierarchical conception of caste, but has Prof. Dharampal read the Dharmaśāstras? How could he deeply ponder the purānic universe that he describes so well without seeing that it is thoroughly hierarchical? He himself admits, as we have seen, that it relegates technology - the aparā vidy $\bar{a}$ - to the ages of decline as a symptom thereof. When souls are at different stages in their transmigratory ascent toward moksa, the idea of hierarchy is unavoidable.

Prof. Dharampal hopes that the present era is "the nether end of one of those cycles of decay of Dharma and its reestablishment that keep recurring" (63-4). However, his readings of the cultural pulse of India remind us of a very different possibility. It is more likely that the Indian tradition - like Christianity - confronts an unprecedented onslaught, in the face of which it is uncertain whether dharma, in the forms it has been known, will survive.
As a Christian who acknowledges a profound spiritual debt to India, and as a scholar who has taken Indological studies as his life's work, I can only agree with Prof. Dharampal's estimate of the urgency of his chosen task. But, however understandable, I find his easy disparagement of Indology and Christianity disturbing. I would suggest that he and his colleagues would do well not to cut themselves off prematurely from any source of aid in the complex work they face. Sympathetic Indologists - and there are such, both in India and abroad - might help provide some greater objectivity. For example, they might question the wisdom of searching for the mind of India through an exclusively Sanskrit vocabulary, ignoring the contribution of Tamils and Muslims, Basava and Kabir, and others. Understanding India in terms of a Sanskritized essence might provide further fuel for Hindu nationalism. But would it promote genuine decolonization, or just more sorrowful manifestations of the colonial trauma?

Christians, including those who have been in India for almost two thousand years, might also provide valuable input. No doubt the western tide that has overwhelmed India is to a considerable degree an outgrowth of Christian culture. But modernity has been an ungrateful child, attacking Christianity equally with other traditions. Christians have devoted considerable effort toward understanding themselves within modernity, and critiquing it. Hindus could learn from their successes, and perhaps equally from their failures.

In an earlier issue of this journal, Francis X. Clooney, S.J., suggested that dialogue between Hindus and Christians is a necessary luxury. ${ }^{2}$ But for those Hindus and Christians who are striving to hold their spiritual centres against a planetary kāla now ruled by modernity and its products, I would say that it not a luxury at all but a simple and pressing necessity. 


\section{Anantanand Rambachan \\ St. Olaf's College}

The Hindu sage Sri Ramana Maharshi (1879-1950) emphasized the primacy of selfinquiry and self-understanding. For this teacher, a proper perspective about human existence is impossible without resolving first the problem of one's identity. Selfknowledge, Ramana Maharshi taught, is the consequence of persistent inquiry into the very source of the "I" thought. The priority which Ramana Maharshi gave to selfunderstanding is reflected continuously in his didactic methodology. He repeatedly guided his questioners to this foundational issue. Ramana's response, for example, to a visitor who inquired about whether God possessed a form or not was typical. Until the visitor could decide whether he had a form or not, argument about God's nature was mere pedantry. When asked about the posthumous state of the human being, the Maharshi pointed out the futility of wanting to know what one will be after death without knowing who one is in the present.

In his small work, Bhäratīya Chitta Mānas and Kāla, Prof. Dharampal argues for the necessity of a similar kind of inquiry. The inquiry is not about the ultimate reality of the human person or of the universe, but some of the presuppositions are the same. Prof. Dharampal issues a call for a continuous inquiry to define the main elements of the Indian "civilizational consciousness". Such a clarification of the characteristic elements of the Indian Weltanschauung is a prerequisite for meaningful and equal interaction with and evaluation of the modern West. As the author puts it, "the questions regarding interactions with others can be addressed only after having achieved some level of clarity about ourselves" (21). The urgency for such an investigation, according to Prof. Dharampal, arises from the state of rootlessness which is evident in the contemporary Indian attitude and conduct. The Indian intelligentsia "seems to have lost all touch with any stable norms of behaviour and thinking. All around, and in all situations, there prevails a sense of confusion and forgetfulness" (32). The source of this rootlessness is the implicit acceptance of the superiority of western modes of thinking and acting, while at the same time being rooted inescapably in the unique consciousness and time (chitta and $k \bar{a} l a$ ) of India. The way out of this absurdity is through the establishment of a "conceptual framework that makes Indian ways and aspirations seem viable in the present, so that we do not feel compelled or tempted to indulge in demeaning imitations of the modern world....And this secure basis for the Indian civilization, this framework for the Indian self-awakening and self-assertion, has to be found mainly within the Chitta and Kāla of India" (16).

Prof. Dharampal expresses particular concern about the assumptions and methodology of Indian scholars studying traditional texts. While acknowledging the labours and contributions of these scholars, the author concludes, however, that "their main objective was to find a place for Indian learning within the various streams of modern western scholarship" (24). They have been concerned with trying to situate the Indian mind within the "world-picture of modernity", rather than trying to make "modernity comprehensible to us, in terms of our Chitta and Kāla" (23). His main point is that Indian scholars have been wittingly or unwittingly studying their society through the tools and categories of the modern West.

Prof. Dharampal's general concern is legitimate and understandable. Those of us who have grown up in colonial communities do not need to be convinced of the pervasive ways in which the institutions, values and beliefs of the colonial powers are assumed to be normative and of the processes by which subjected people view and evaluate themselves through colonial eyes. It is not 
unusual for a colonized people, educated in the institutions of the colonizer, to be anxious to show that they are not deviators from the canons of the latter and to labour to vindicate themselves in the colonizer's eyes. Such labours often assume ludicrous forms, but proceed on the assumption of the superiority of the colonizer's yardstick. Prof. Dharampal gives the example of Indian scholars working assiduously to show that the attributes of the modern West were already discovered and affirmed in India's ancient literature!

Religious traditions and cultures, emerging from long periods of colonial domination, must ask again, with new vigour, the ever relevant question, "Who are we?" This question assumes multiple meanings when the questioner struggles, not only to define himself from the perspective of his own religious heritage, but to untangle also the internalized assumptions and ways of seeing himself through the eyes of others. It is often too easy for the Hindu who is involved in interreligious dialogue with the Christian to fall into the habit of striving assiduously to show that the insights of Hinduism do not differ, in essentials, from those of Christianity. One's contribution to the encounter of religions is greatest when one is able to offer, humbly, at the table of mutual inquiry and respect, the uniqueness of one's perspective and experience of the Ultimate. The search for and recovery of this uniqueness, however, is a prerequisite for being able to offer it to the other. Like the offering that one makes and then receives as prasādam in a Hindu temple, one's special gift of understanding may be received again with enrichment and enhanced meaning.

While I am supportive, therefore, of the broad concern of Prof. Dharampal's thesis, I see his argument as an opportunity for a constructive discussion on the nature of the Indian consciousness and the methods for determining its contents. His thesis assumes the reality of a distinctive Indian civilizational consciousness and our ability, in the present, to recover and define the principal elements of such a consciousness. Both of these assumptions may be correct and Prof. Dharampal attempts (chapter 4) to outline some of these distinctive elements. This is undoubtedly an exciting venture. It must, though, be of some significance that Prof. Dharampal chooses to characterize this consciousness by a term that is suggestive of a national identity (Indian) rather than one with religio-cultural connotations (e.g. Hindu). Although the author acknowledges, somewhat tentatively (17), that elements of the Indian consciousness may have been contributed by Gautama Buddha or Mahāvīra, the textual sources which he cites as necessary for probing the Indian mind and the elements of that mind which he identifies are all traditionally Hindu. Perhaps Prof. Dharampal is reluctant, for valid reasons, to employ the term "Hindu" or perhaps he can argue, legitimately, for subsuming all that is implied by the latter in the wider national category. One must admit, at any rate, that there are dangers and difficulties in the implicit or explicit equation of both terms.

Prof. Dharampal is not unaware of the diversity that is included in his preferred category. He refers to "some sections of the Indian people who do not subscribe to the traditional Indian understanding of creation and unfolding of the Universe" (59) and mentions, in the same context, the Indian Muslims, Christians and Parsis. Such differences, in the author's view, are minimal. Who decides, one must ask, whether particular differences are insignificant or weighty? The method suggested by Prof. Dharampal for comprehending the Indian mind is the study of India's ancient literature and the sources which he mentions, like the Rgveda, the Upanishads, the Purānas, the Mahābhärata, the Rämäyana and the canons of Buddhism and Jainism, are seminal. In the search for the Indian consciousness, however, investigation of ancient textual sources must be pursued side by side with dialogue among 


\section{Prof. Dharampal's Bhāratīya Chitta Manas and Käla}

the diverse contemporary communities who have made the Indian sub-continent their home. Such dialogue ought to be conducted in ways that allow these communities to freely define themselves and the essential elements of their particular or shared identity. Such conversations must be an indispensable part of the quest for selfdefinition in India. In the absence of such dialogue, there is the perilous risk of generalizations and assumptions which are imposed by one community upon another and one discerns in Prof. Dharampal's arguments a tendency to such sweeping generalizations. In one instance, for example, the author writes of "the western man's innate sense of total subordination to the prevailing system, a subordination of the mind that man in the West has always displayed irrespective of whatever the system was in any particular western phase, whether it was a despotic feudal oligarchy, a slave society like that of ancient Greece and Rome, a society of laissez faire, or of marxist communism, or the currently ascendant society of market forces" (61). Such an indiscriminate generalization about the consciousness of the western individual can hardly endure the light of historical reality.

The task of searching for the Indian civilizational consciousness, which Prof. Dharampal charts for us, underlines the necessity for dialogue among the various religious communities in India. While Hindus ought to embrace opportunities for dialogue with Christians, there must be attentiveness also to the need for and the enriching possibilities of dialogue with Buddhists, Jains, Parsis, Muslims, Jews and Sikhs in the Indian context. The significance of such conversations is often overlooked by Hindus who tend to minimize differences. Such dialogue among the traditions of India will have beneficial effects on any subsequent conversations individual groups may have with Christians. In seeking to understand another community, whether that community exists within or outside one's own geographical boundaries, one's own perspective, contrary to the author's claim (20), is not the only vantage point. His argument about the need to define and apply one's own perspective is valid, but this perspective must be informed and modified by the articulated self-understanding of the other. I have already cited what I consider to be an unfair generalization about the consciousness of the western individual from the author's perspective.

The need for deliberation about the process of searching for the Indian consciousness and the dangers of subsuming all darśanas in one's own are evident also in the elements of the Hindu tradition cited by the author. I am sure that Bhäratīya Chitta Manas and Käla is not an exhaustive statement of Prof. Dharampal's thinking, but his references to Hinduism in this work are, nevertheless, revealing. While Prof. Dharampal may have cogent reasons for his selectivity, it appears the vital elements of the Indian consciousness, as he delineates it, are derived from the non-dual traditions of India. One may advance the claim that Advaita (Non-duality) is the most distinctive element of the Indian outlook, but such a claim cannot be made a priori and by the exclusion of other perspectives. Two examples will suffice. Writing about the problems of the relationship between apara vidya and parā vidya $(50-1)$, the author suggests that contempt for the former is perhaps not fundamental to the Indian consciousness. The earlier idea may have been "that while dealing with Aparā, while living within the complexity of the world, one should not forget that there is a simple undifferentiated reality behind this seeming complexity, that there is the unchangeable Brahman beyond this ever-changing mundane world". Later on, he writes about "the peculiarly Indian belief, which even the most ordinary Indian harbours in his heart, that he is a part of the ultimate Brahman, and by virtue of this relationship with Brahman, he too is completely free and sovereign in himself" (61). 
In these brief remarks, I have given support to Prof. Dharampal's plea for selfdefinition and for the recovery of characteristic elements of the Indian outlook, while expressing some of my concerns about the methodology of this enterprise and Prof. Dharampal's attentiveness to the diversity of the Indian mental landscape. Finally, while I agree with the author that the task of constructing "this conceptual basis for Indian thought and action" must be undertaken by Indians, I disagree with his claim that outsiders have little to contribute (38). Distance and detachment often enable the outsider to perceive aspects of our outlook which we may take for granted and we often see ourselves clearer when we look through the eyes of others. While Indology, in its origin, may indeed have been "the science of comprehending India from a nonIndian perspective" (23), we cannot ignore, as Prof. Dharampal does, the significant progress which has been made since then. There has been significant scholarship by western and Indian scholars trying to understand and describe India on its own terms and such studies can contribute to the search for India's vision. The claim that all western scholars and Indian Indologists "have been merely searching for occasional scraps of contemporary relevance from the remains of a civilization that for them is perhaps as dead and as alien as it is for the West " is another example of a questionable generalization which deflects from the serious concerns of Prof. Dharampal's work.

\section{Nilima Chitgopekar Jesus and Mary College}

The essay by Prof. Dharampal entitled Bhāratīya Chitta Manas and Kāla emphasizes the urgent need to understand the "Indian Mind", "Indian Consciousness", supposedly to save the country from imminent disintegration and destruction. This apocalyptic vision is exemplified in six sections. Attempting a thematic study would not only have made the methodology more systematic but the reading easier. Unfortunately we find themes overlapping in all the sections.

The turning point, or rather the raison d'etre for writing this booklet, is provided in the preface. The motivation seems to have been the "precipitate action" (5) on the Babri Masjid in December 1992, which according to the preface was done by "the people" of India to remind the ruling elite that they do not particularly relish the persistent insults to their civilizational sensibilities. However, at the outset it may be stated that the "action" (a euphemism that makes one distinctly uncomfortable) on the Babari Masjid was a very unfortunate happening that not only destroyed a historical monument but precipitated widespread rioting and bloodshed. That it did occur is a frightening reality that should be and is being studied in almost all intellectual and other circles. I am not sure whether the path Prof. Dharampal is strongly recommending is the apt one. However, as an attempt to suggest one, it is worth reading.

The entire booklet disturbed me considerably. The sections that I am commenting on are sections II and III. However, since there are, as I stated earlier, no clear demarcations in themes, I will be referring to parts of other sections as well.

In section II Prof. Dharampal states that the way of saving India would be to understand the Indian Chitta and Käla. The way to begin would entail studying the vast corpus of literature that has formed the basis of Indian civilization and regulated the actions and thoughts of the people of India for millennia (22). An overview of texts like the Rgveda, the Upanishads, the Epics and 
the Purānas should provide us with a preliminary picture of the Indian mind, by showing us what they say about Indian ways and preferences - which Prof. Dharampal feels have to be understood. In order to study these texts a thorough knowledge and competence in Sanskrit should be there. Prof. Dharampal laments the fact that there are so few involved in the study of Sanskrit and he criticizes the education system in India for being influenced by the West (24-7). The apparatus of education in India as in other parts of the ancient world, it must be remembered, was tied up with ecclesiastic interests on the one hand, and those of the ruling elite on the other. There is a cultural imperialism if we live in the past. This is because the process of learning was an exclusive preserve based on caste. In a country where religion was always and is always inextricably interwoven with social developments, it is commendable that we have tried and continue to try to remove ourselves from the past. We believe that every present has the right and even the duty to discard much of its own past, especially those particular traditions which have become "irrational" and yet survive as signs of stasis in popular life or as oppressive encrustations in the social make-up. Sanskrit is the language of a hierarchical and institutionalized religious order, standing above and in opposition to all vulgates and vernaculars. It has been the language of "high" culture for centuries. High Brāhmanism always sought a kind of homogenization of populations in belief systems and social practice; it assigned to itself a sort of cultural supremacy, a special relation with the language of belief and command and an agential role as the ideological guardian of the Indian systems. It must be remembered that in a multireligious, multilingual country like India there are regionally differentiated idioms of culture and language. There is a cultural fragmentation that in fact should be recognized.
The texts Prof. Dharampal refers to moreover reflect overtly and explicitly the dominant hegemonic section of society. For example, they underscore the caste system as a suitable system for maintaining the status quo. They also usually privilege the role of men over the submissive role of women, amid other evils of society, as an essential part of the Indian ethos. They reveal unjust treatments to minoritized sections of society which should not be valorized or glorified any longer.

The structure of disseminating knowledge was therefore somewhat closed. Nobility of birth as a prime qualification for undergoing the process of learning is constantly stressed in the "traditional organization of learning in India" (124). This is why universities of Indian learning were probably conceived along the lines laid down by western scholarship. The acceptance of a more modern, albeit western, model of governance was also bound to occur. It does not seem to be a blind following of western ideals in polity as Prof. Dharampal suggests, but is in large measure an indigenization of a western framework. This framework has the advantage of being a time-tested one. India in ancient times also had not seen the entire country being governed or unified under one central government. Diffused polities with smaller autonomous units were the political, social and economic structure that India had been accustomed to. Some adaptation was necessary. In the absence of an a priori experience of government, the western one was far more suitable than one which was steeped in tradition. Prof. Dharampal wants us to take the help of ancient texts for rewriting and reasserting our civilizational thrusts (22-3). It must be stressed that we cannot randomly take up that literature and those ideals, riding roughshod over subsequent centuries and the influence the literature of those periods would have had, and try to establish traditional ideals. Those texts were clearly written to suit a particularly social and economic milieu. A 
lot has changed since then. There have been countless influencing factors on the "Indian way of thinking". I am concerned about the author's notion and implication that there is one universal idea, one aspiration of the entire people of India. The caveat, the fascination and the exasperation for those who work on India or who have anything to do with India, lies in the fact that India does not have one homogeneous Indian people, only peoples. There are variables and differentiations and pluralisms at all levels which negate the possibilities of trying to impose a particular thinking on the people. Since time immemorial there has been a dispersal of cultures and traditions each with their own regional affinities and royalties. The nurturing of the idea that there can be a uniform code of social behaviour based on randomly selected "scriptural" texts is not the answer. It is true that maybe a conceptual ground should be there in order to "firmly stand and have a look at the world" (29), but I am not sure whether this can be achieved by understanding our Chitta and Käla. Just the idea that there can be an Indian view of the world - a unitary, monolithic, singular idea of such a composite and complex society - is not only unrealistic but perilous as well, so asking for a "rough and ready comprehension..." (29) of ourselves and the world is also not possible. The author is asking us to critique everything western: "Ridding ourselves of the western ways of thought and action we shall have to start understanding ourselves and the world from our own civilizational perspective" (62). Getting rid of western ways of thought would be tantamount to erasing nearly two hundred years of our history. We cannot seek what we want from certain texts belonging to the remote past without considering the impact made by the intervening, intermediary period. Certainly it too has left its own indelible mark on the Indian mind and the Indian civilization. The author does not mention the medieval/Mughul period or the British period of Indian history. We cannot wish them away. We are, as a civilization, a product of all the cumulative epochs. This is an inescapable, if for some uncomfortable, fact for those who claim that everything Indian goes back to the Rgveda or the Mahäbhärata, riding roughshod over more recent occurrences. This is in tune with viewing Hinduism as a monolithic, pristine entity that has come to us unchanged through the millennia (23). History stands testament to a constant influx of ideas in the realm of sculpture, architecture and even religion. The dissemination and proselytizing trait of Indians and of Hinduism is what we take pride in. Moreover, with all the different types of people in India, will they all be able to identify with notions of Chitta and $K a \overline{l a}$ as presented or found in the Purānas and Vedas? Here I am referring to Christians, Muslims, Parsis, etc.

The entire discourse on education is thought-provoking (35-7). However, we find Prof. Dharampal floundering into a discussion that may appear naive and at times ill-informed. He seems to believe that Indians are learning or speaking English because the Americans or the western English-speaking world are the current masters of the world (37). That is not how we view the situation in India. As mentioned earlier, British rule lasted for two centuries. It has willy-nilly left its influences on us. We cannot wish them away. Today we speak English and try to remove linguistic barriers as far as possible. Prof. Dharampal refers to Bhojpuri and asks: "Will a person who is familiar with Bhojpuri be considered literate, will he qualify as an educated person or should he know at least Nagari Hindi?" That is exactly the point. Will the knowledge of Bhojpuri or Hindi be useful to someone in the south of India, for example? Can English provide some kind of link between the different regions? Secondly, the English we speak is our own English, it is neither American or British, but an English that has evolved in India over the centuries, to suit the Indians. I am aware of the elitist stamp that might befall these statements, but 
we are all endeavouring to grapple with the problem of the non-existence of a language that can be a cementing force, a unifying factor and yet please everybody.

There are several ways of studying Indian literature. Many enlightened Indian scholars want to approach this mass of literature holistically - that is, by trying, endeavouring to comprehend the background of the period in which it was written and also the background, if possible, of the authors involved.

Reading a historical text, understanding the milieu in which it was written or composed helps in understanding the contextual element. The milieu will include the regional and chronological contexts. In a country that has not shared a common history, let alone common cultural idioms, to attempt to impose them, on the threshold of the twenty-first century, appears naive and shortsighted.

I am also disturbed as to who the audience is that Prof. Dharampal is addressing. This confusion I seem to share with the author. Is he approaching the grhastha, scholars, scientists, the labourer on the street, the housewife? (63).
Elsewhere (59) the author says that, "Reassertion of India in the present context is the major task which Indian scholarship, Indian politics, Indian sciences and technologies, Indian arts, crafts and other diverse skills must accomplish".

In our thinking we should try and infuse more justice into systems of thought. Ideally, we should try and rid ourselves of unprogressive, oppressive signs from the tradition and retain those which give us an identity, but also help us to merge and tolerate others (32). There are many leading problems that Indians should be tackling headlong: provision of drinking water, primary education, employment, matters pertaining to ecology. These should be given primacy. Trying to lessen the chasm between the haves and the have-nots would be an achievement.

No one is trying to abruptly transform a traditionally religious society, but one is trying to bring the world closer by seeking similarities in certain humanitarian ideas. One is trying to draw out a framework where being a good person becomes very important and this should be the main thrust of any civilization.

\section{Anand Amaladass, S.J. Institute of Philosophy and Culture, Madras}

Prof. Dharampal's book sets out to look for a conceptual framework that makes Indian ways and aspirations seem viable in the present. He pleads for the rediscovery of the Indian spirit and the return of India to its civilization and tradition as enshrined in our literature. He raises valid questions and makes people think. His search for Indian mind and consciousness is challenging. His concern for the ordinary people in India who live chronologically in the twentieth century and think and act psychologically in the eighteenth century is to be appreciated. $\mathrm{He}$ is critical of the extreme reactionary attitudes of Indians: one group finding nothing positive in India seeks to write on an Indian clean slate what they have learned from the West, and the other group discovers everything of the modern world already seminally contained in the ancient literature of India. Avoiding these extreme groups he finds a way of interacting with the twentieth century West after achieving some level of clarity about ourselves.

On the positive side, the author of this book has something interesting to say. He says that the effort to construct a framework for Indian thought and action is not to be confused with the search for the ultimate truth of India - sanātana. We only need 
some basis from which to start asking the appropriate questions. There will never be any final answers. But the fact of having raised the right questions would have provided us with some directions to the right path.

He quotes two examples to illustrate his point - one from the Rāmāyana and the other from the Mahābhärata. Sita questions Rama about the violent tendencies that she discerns arising in Rama. She warns Rama against the warlike inclinations that the possession of weapons invariably generates. Sri Rama did reply to the question Sita raised about his warlike demeanour in the forest. But it is the questioning that is important; not so much the answers. What is important is to keep raising questions about human conduct in various situations, not necessarily to arrive at final prescriptions (39).

The second example is a dialogue between Bhrgu and Bharadvaja in the Mahäbhärata. Bhrgu initiates the dialogue with his teaching that after creating the humans and other beings, Brahmā classified the former into four different varna. Bharadvaja asks for the basis of the differentiation. Sweat, phlegm, bile and blood circulate within everyone. Then on what basis is the varna divided? Bhrgu answers that originally there was no distinction among the people. At the beginning all were of the same varna. But with the passing of time they began to differentiate into different varnas according to their karmas. But Bharadvaja persists with his questioning. But there are no final answers given in the text.

Perhaps their way of questioning is the Indian way. To keep asking questions about personal and social conduct and about the appropriate modes of social organization and to keep finding provisional answers in various contexts, this way of continuous awareness and continuous reflections is perhaps the essence of the Indian way of life. We have somehow lost this habit of constant questioning and the courage to question.
If we only start raising those questions again, we may regain some anchorage in our chitta and kāla (40).

This continuous questioning, reinterpretation and renewal of the tradition is what the rsis and munis and other great scholars of India have been concerned with through the ages. The author gives two criteria to guide any meaningful interpretation: one is the sense of compassion that the interpreter feels for his fellow beings; the other is an abiding faith in the inherit soundness and strength of the Indian tradition. That is quite insightful. Such a conclusion is a creative contribution to the progress of tradition, in the sense of interpreting the past for the present and future generation.

Prof. Dharampal is uneasy about the Indians who have adopted western values and attitudes. He is also negative about the Indological research done in India with western methods. One cannot afford to be isolated while reading and interpreting the Indian texts. Awareness of modern western methods and their discipline has become part of Indian consciousness. In a way it provokes, challenges, questions our traditional way of going about things. This process of exposure is a risk, because it challenges us, questions sometimes all that we cherish as dear. It might disillusion some of us about our own world, but it can also draw us back into what is genuinely Indian. So there is no need to feel uneasy or threatened. The risk is worth taking for the discovery. In fact the whole search for the Indian mind and way of thinking undertaken by Prof. Dharampal results from the confrontation with another culture. If he had not been thus confronted, he would not have undertaken this trouble and come out with an enriching discovery of what is the essence of the Indian way of thinking, and so on.

Secondly, one need not be negative about Indological research done with the western method. It is true that westerners cannot fully understand Indian tradition just as Indians cannot understand the western 
mind and values fully, even if the Indians read western history and literature, speak their language, listen to the $\mathrm{BBC}$ and die Deutsche Welle. But the efforts of the western Indologists are great and their contribution to Indian studies is enriching and praiseworthy and that needs to be acknowledged.

Today interaction is unavoidable. It is even a necessary process for our healthy growth and identity. The search for our Indianness is provoked by the confrontation with another culture. It was not perhaps the problem of our ancient thinkers. Our ancient thinkers like Samkara and Ramanuja did not ask what was Indian about what they wrote. Today we need to ask that question, we need to articulate for ourselves what is Indian about Indian philosophy and so on, while we are interacting with our counterparts in the West. That is part of the process of understanding and interpreting our own tradition, and integrating ourselves with it in today's context. That is participating in the wider tradition, or philosophizing in the Aristotelian sense - by listening to the numerous voices in answering the universal questions of life and adding our own graciously.

One can understand the concern and anguish of Prof. Dharampal when he says that Indians should find their own style of government, since the system bequeathed by the British does not suit Indian consciousness, and his consequent annoyance with those who have adopted western values and are trying to transcend the Indianness in them. The concern is genuine, and one should look at it with sensitivity in the context of what is happening around the world - people struggling and even waging wars to find their ethnic, linguistic, religious, national and cultural identity. On the one hand, there is the valid human search to find one's identity in terms of one's cultural and religious traditions. But this search does not end within one's own limited, national, cultural boundaries. There is, on the other hand, an urge in all of us to transcend the "boundaries" of culture, religion and philosophy as human beings. After all, what is genuinely human has a universal dimension, which is valid for all, irrespective of the geographical and cultural boundaries in which one happens to be born and brought up. In that sense, any culture has something unique about it, offering a challenge to any open-minded person. Hence one cannot speak always in terms of EastWest or North-South values, when some, who have the opportunity to be exposed to different traditions, adapt and even adopt new ways of thinking, different from the one ones in which they were born. After all what are the factors that define our identity and ensure security? It is true, the conflict of values in such a process is real and one has to face the challenge in one's own actual living context. But there is no need to be alarmed if some people adopt "western" or "eastern" values, if the human in them finds a vision and provides meaning in their life enabling them to be open to and appreciative of others.

Finally, the project of Prof. Dharampal - what is Indian mind and consciousness - is a valid quest for self-identity. This search for Indianness has to take into account one's personal and national history, its religious and secular traditions, its cultural heritage as enshrined in art and literature. In India such a heritage is multi-faceted due to its past history. Though the major tradition is Hindu - which one has to admit in identifying the Indian identity - one cannot absolutize this, as if India's past is of a mono-cultural tradition. What about the "Indianness" of those others who do not directly belong to the major literary tradition of Hindu religious culture - like the tribals, the dalits, the Muslims and the Christians in India? They have other literary and religious traditions, which define their identity in the Indian soil, without denying the contribution of the typically Hindu culture in shaping their Indian identity in some form or other. 
This comment is made in all fairness to Prof. Dharampal's insight into ancient Indian literature. He finds that the essence of Indian tradition is raising basic questions and finding provisional answers in a given historical context, which should not be absolutized as the perennial solutions for all time. If this is the insight of Prof. Dharampal from the ancient Indian literature of Hindu religious tradition, a similar search into other, minor traditions of India should lead us to follow this clue and see whether there is also such a questioning culture in these traditions, which have become part of the Indian culture today. That leads us to intercultural and interreligious dialogue enabling us to carry forward the insight of Prof. Dharampal and to critique all the components of Indian culture - great and small traditions in India. Thus this book is challenging to all Indjans, irrespective of which tradition they belong to.

\section{Notes}

1. All page references are to Prof. Dharampal's Bhäratīya Chitta Manas and $K a \bar{l} l a$, tr. from the Hindi by Jitendra Bajaj. Centre for Policy Studies: Madras, 1993. Cited with permission of the publisher.

2. "Hindu-Christian Studies as a Necessary Luxury in the Context of Today's Pluralism." Hindu Christian Studies Bulletin 7: 39-44. 